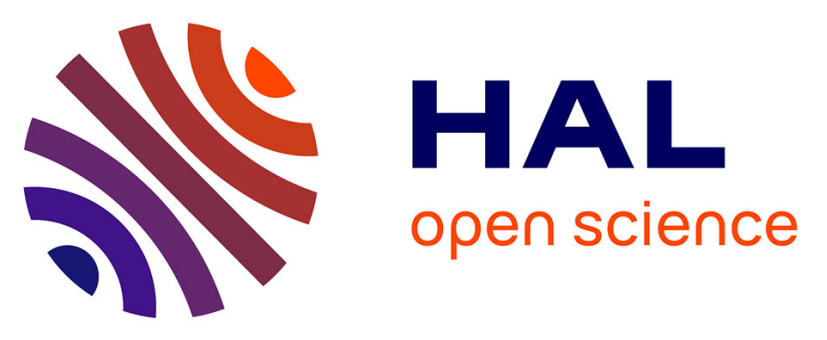

\title{
Rhenium and Manganese Complexes Bearing Amino-Bis(phosphinite) Ligands Synthesis, Characterization, and Catalytic Activity in Hydrogenation of Ketones
}

Haoran Li, Duo Wei, Antoine Bruneau-Voisine, Maxime Ducamp, Mickael Henrion, Thierry Roisnel, Vincent Dorcet, Christophe Darcel, Jean-François Carpentier, Jean-François Soulé, et al.

\section{- To cite this version:}

Haoran Li, Duo Wei, Antoine Bruneau-Voisine, Maxime Ducamp, Mickael Henrion, et al.. Rhenium and Manganese Complexes Bearing Amino-Bis(phosphinite) Ligands Synthesis, Characterization, and Catalytic Activity in Hydrogenation of Ketones. Organometallics, 2018, 37 (8), pp.1271-1279. 10.1021/acs.organomet.8b00020 . hal-01807088

HAL Id: hal-01807088

https://hal-univ-rennes1.archives-ouvertes.fr/hal-01807088

Submitted on 20 Jun 2018

HAL is a multi-disciplinary open access archive for the deposit and dissemination of scientific research documents, whether they are published or not. The documents may come from teaching and research institutions in France or abroad, or from public or private research centers.
L'archive ouverte pluridisciplinaire $\mathbf{H A L}$, est destinée au dépôt et à la diffusion de documents scientifiques de niveau recherche, publiés ou non, émanant des établissements d'enseignement et de recherche français ou étrangers, des laboratoires publics ou privés. 


\title{
Rhenium and manganese complexes bearing amino- bis(phosphinite) ligands: synthesis, characterization and cat- alytic activity in hydrogenation of ketones.
}

\author{
Haoran Li, ${ }^{\mathrm{a}}$ Duo Wei, ${ }^{\mathrm{a}}$ Antoine Bruneau-Voisine, ${ }^{\mathrm{a}}$ Maxime Ducamp, ${ }^{\mathrm{a}}$ Mickaël Henrion, ${ }^{\mathrm{a}}$ Thierry Rois- \\ nel, ${ }^{\mathrm{a}}$ Vincent Dorcet, ${ }^{\mathrm{a}}$ Christophe Darcel, ${ }^{\mathrm{a}}$ Jean-François Carpentier, ${ }^{\mathrm{a}}$ Jean-François Soulé ${ }^{\mathrm{a}}$ and Jean- \\ Baptiste Sortais $^{\mathrm{a}, \mathrm{b}, \mathrm{c} *}$.

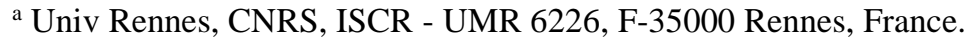 \\ ${ }^{\mathrm{b}}$ LCC-CNRS, Université de Toulouse, CNRS, UPS, Toulouse, France. \\ ${ }^{\mathrm{c}}$ Institut Universitaire de France, 1 rue Descartes, 75231 Paris Cedex 05, France. \\ Supporting Information Placeholder
}

\begin{abstract}
A series of rhenium and manganese complexes supported by easily accessible and easily tunable aminobisphosphinite ligands was prepared and characterized by NMR and IR spectroscopies, HR mass-spectrometry, elemental analysis and X-ray diffraction studies. These complexes have been tested in the hydrogenation of ketones. Notably, one of the rhenium complexes, bearing a NH-moiety, proved significantly more active than the rest of the series. The reaction proceeds well at $120^{\circ} \mathrm{C}$, under 50 bar of $\mathrm{H}_{2}$, in the presence of $0.5 \mathrm{~mol} \%$ catalyst and $1 \mathrm{~mol} \%$ of $t \mathrm{BuOK}$. Interestingly, activation of the precatalyst could be followed stepwise by NMR and a rhenium-hydride was characterized by X-ray diffraction studies.
\end{abstract}

\section{INTRODUCTION}

For several decades, since the discovery of Wilkinson's catalyst, the design of homogeneous hydrogenation catalysts has been based on transition metals belonging to groups 8-10, typically iron, cobalt, nickel and Precious Group Metals. ${ }^{1}$ Comparatively, hydrogenation catalysts based on group 7 transition metals were quite elusive. ${ }^{2}$ In the case of manganese, hydrogenation of alkenes, with either molecular dihydrogen or under water gas shift and synthesis gas conditions, was sporadically described until recently. ${ }^{3}$ With rhenium, after the early work of Ephritikhine ${ }^{4}$ and Caulton, ${ }^{5}$ the group of Berke explored the application of a few nitrosyl (poly)-hydride complexes (e.g. complex I, Chart 1, as a representative example) for the hydrogenation of olefins and nitriles. ${ }^{6}$ The same group also demonstrated that the rhenium analogue (complex II, Chart 1) of Shvo's catalyst is active for the reduction of ketones by transfer hydrogenation, using 2-propanol as hydrogen donor. ${ }^{7}$ Also, Gusev reported the reduction of acetophenone, by hydrogen transfer, using a $\mathrm{PN}(\mathrm{H}) \mathrm{P}$ nitrosyl rhenium complex (complex III, Chart 1). ${ }^{8}$

However, the association of tridentate PNP ligands and rhenium in coordination chemistry is quite rare $^{8-9}$ and the catalytic

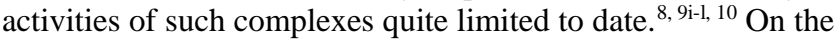
opposite, the application of PNP-Mn complexes in hydrogenation and related reactions has seen an impressive explosion in catalysis within only a year. ${ }^{11}$

Among the various tridendate ligands developed, ${ }^{12}$ aliphatic $\mathrm{PN}(\mathrm{H}) \mathrm{P}$ ligands, also called "MACHO" type ligands, ${ }^{13}$ have been demonstrating a broad versatility with a number of non- noble transition metals to promote hydrogenation reactions $\left(\mathrm{Fe},{ }^{14} \mathrm{Co},{ }^{15} \mathrm{Ni}^{16}, \mathrm{Mn}^{11,}{ }^{17}\right)$. Yet, one drawback of these ligands is their high price and relatively low modularity or difficulty of synthesis. ${ }^{18}$

Recently, we have described the first example of rheniumcatalyzed hydrogenation of carbonyl derivatives, with a broad scope and high activity. ${ }^{10 a}$ The catalyst we used (complex $\mathbf{V}$, Chart 1) was based on the typical bis(diisopropylphosphinoethane)amine ligand, and we have shown, with the help of DFT calculations, that the reaction proceeds through heterolytic cleavage of dihydrogen by a metal-ligand cooperative mechanism. ${ }^{19}$ Since the development of cooperative strategies in hydrogenation is of high interest to develop efficient catalytic systems, ${ }^{20}$ we were looking for easily accessible ligands, with a higher degree of modularity.

With these aims, we turned our attention toward simpler ligands with phosphinite moieties, ${ }^{21}$ synthesized in one step from the readily available corresponding alcohols and chlorophosphines. In particular, we have been interested in the application of amino-bisphosphinite ligand (PONOP), initially developed by Stephan. ${ }^{22}$ In association with ruthenium (complex VI, Chart 1), the hydrogenation of aromatic and aliphatic esters was achieved. ${ }^{23}$

In this contribution, in line with our interest in group 7 catalysts for reduction reactions ${ }^{24}$ we have prepared a series of new rhenium and manganese complexes bearing aminobisphosphinite ligands. A comparison of the catalytic activity in hydrogenation of carbonyl derivatives was achieved, using catalyst $\mathbf{V}$ (Chart 1) as benchmark. 


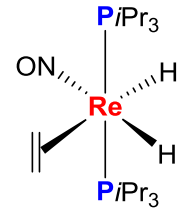

I

Berke, 2008

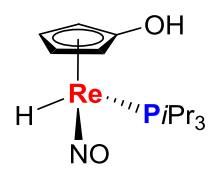

II

Berke, 2012

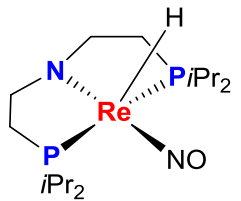

III

Gusev, 2007

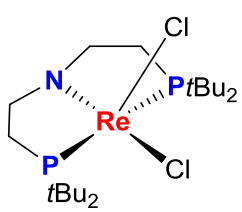

IV
Schneider, 2014

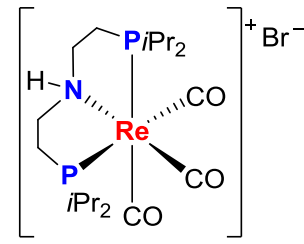

V

our work, 2017

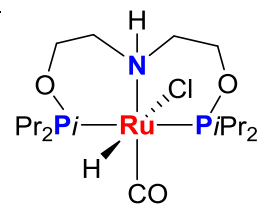

VI

our work, 2017
Chart 1. Representative rhenium-based catalysts (I-V) and PNP complexes (III-VI)

\section{RESULTS AND DISCUSSION}

\section{Synthesis of rhenium and manganese complexes.}

Three bis-aminobis(phosphinite) ligands 1a-3a, substituted at the nitrogen by $\mathrm{H}, \mathrm{Me}$ and $\mathrm{Bn}$, respectively, were readily prepared in high yield from the corresponding diethanolamine and chlorodiisopropylphosphine in THF in the presence of $\mathrm{Et}_{3} \mathrm{~N}$ following literature procedures (Scheme 1). ${ }^{22}$

\section{Scheme 1. Synthesis of PONOP ligands 1a-3a.}

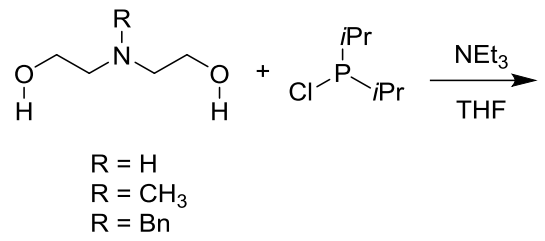

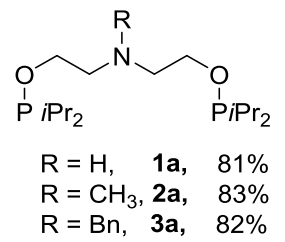

Rhenium 1b-3b and manganese 1c-2c complexes were synthesized starting from $\mathrm{M}(\mathrm{CO})_{5} \mathrm{Br}(\mathrm{M}=\mathrm{Re} / \mathrm{Mn})$ and the corresponding ligand by heating at toluene reflux overnight (Scheme 2). Rhenium complexes were obtained as off-white solids in excellent yields after one recrystallization step, and manganese ones as orange powders. Note that in the case of ligand 3a and manganese, a black oily crude product was obtained and could not be purified. All the complexes were fairly stable to air and moisture and could be handled without special precautions; yet they were best stored under argon in the dark at room temperature.

Scheme 2. Synthesis of rhenium (1b-3b) and manganese (1c-2c) complexes.

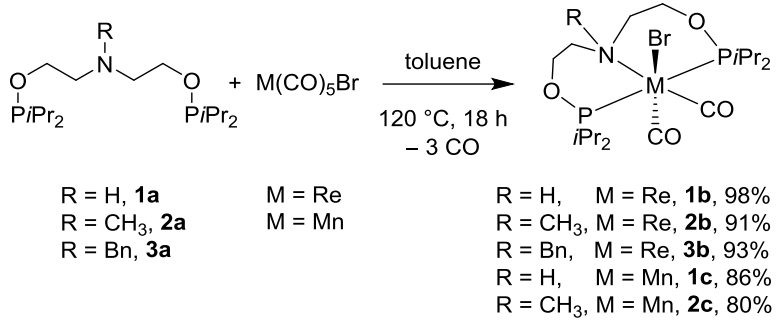

All the complexes were diamagnetic and were fully characterized by NMR $\left({ }^{1} \mathrm{H},{ }^{13} \mathrm{C}\right.$ and $\left.{ }^{31} \mathrm{P}\right)$ and IR spectroscopies, HRmass spectrometry and elemental analysis. Coordination of the tridentate ligand was confirmed by the presence of a single signal in the ${ }^{31} \mathrm{P}\left\{{ }^{1} \mathrm{H}\right\}$ NMR spectra (for rhenium complexes: $\delta$ $128.8,130.1$, and $129.4 \mathrm{ppm}$ for $\mathbf{1 b}, \mathbf{2 b}$, and $\mathbf{3 b}$ respectively; for manganese complexes: $\delta 174.7$ and $172.2 \mathrm{ppm}$ for $\mathbf{1 c}$ and 2c, respectively). In contrast with our previous synthesis of complex $\mathbf{V}$, and similar PNP and $\mathrm{PN}^{3} \mathrm{P}-\mathrm{Mn}$ complexes, for which cationic tricarbonyl complexes were obtained alone or as a mixture of neutral and cationic compounds, with this family of PONOP ligands, neutral dicarbonyl complexes were exclusively obtained, as confirmed by elemental analysis.

The molecular solid-state structures of the five complexes were also confirmed by single crystal X-ray diffraction studies. Representative perspective figures are disclosed in Figures 1-5 for $\mathbf{1 b}, \mathbf{2 b}, \mathbf{3 b}, \mathbf{1 c}$ and $\mathbf{2 c}$, respectively. In all the cases, the metal lies in an octahedral environment, the tridentate ligand being in a meridional coordination mode, and the two carbonyl ligands in cis-position. The bromide atom was found randomly in cis or trans position with respect to the substituent on the nitrogen atom. The meridional coordination of the PONOP ligand contrasts with the facial arrangement observed in complex $\mathbf{V}$ (Chart 1). This isomer corresponds to the most stable one, compared to the facial one according to DFT calculations performed by us and others. ${ }^{8,}$ 10a In line with this geometry, Tisato and Bolzati have found that in the case of $\left[(\mathrm{PN}(\mathrm{H}) \mathrm{P}) \mathrm{ReCl}_{3}\right]$ meridional coordination is also preferred. ${ }^{\text {9e-g, }}$ 25

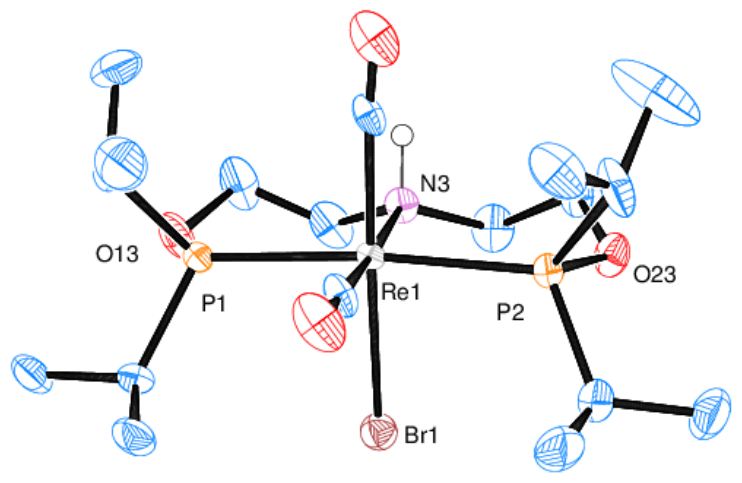

Figure 1. Perspective view of the molecular structure of complex 1b with thermal ellipsoids drawn at $50 \%$ probability. Hydrogen atoms, except $\mathrm{NH}$, were omitted for clarity. The bromide atom is disordered over two positions, only one of which is depicted. 


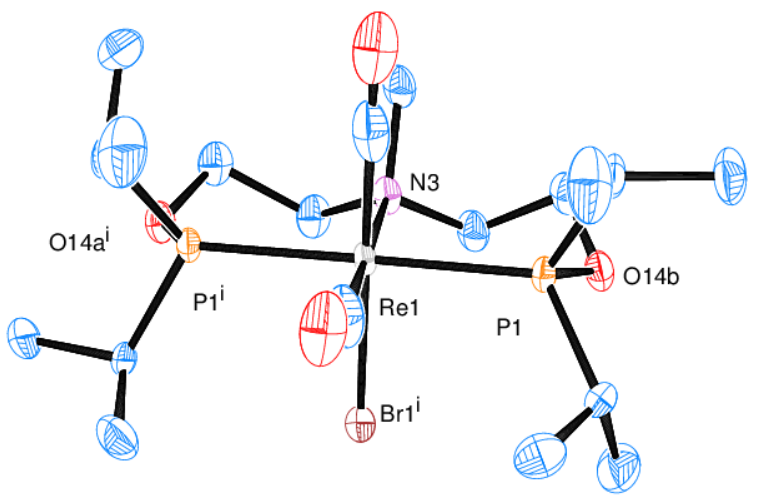

Figure 2. Perspective view of the molecular structure of complex 2b with thermal ellipsoids drawn at $50 \%$ probability. Hydrogen atoms were omitted for clarity. Two configurations of the compound are superimposed in the crystal structure, only one is depicted.

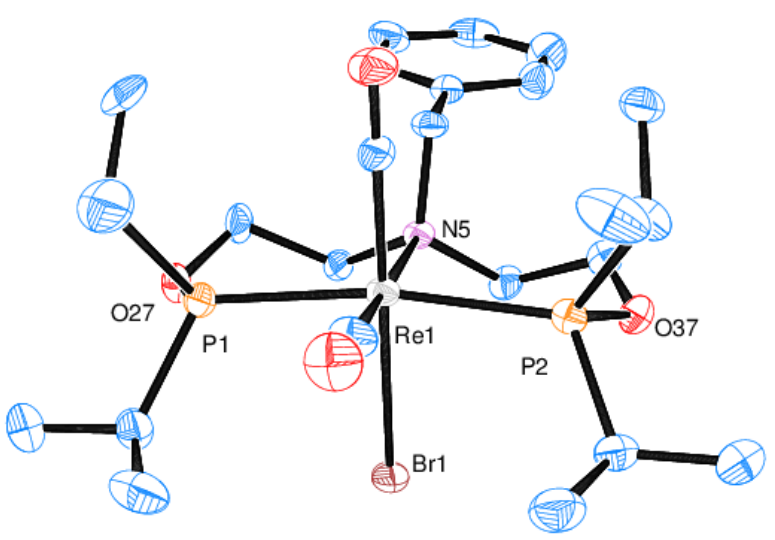

Figure 3. Perspective view of the molecular structure of complex $\mathbf{3 b}$, with thermal ellipsoids drawn at $50 \%$ probability. Hydrogen atoms were omitted for clarity.

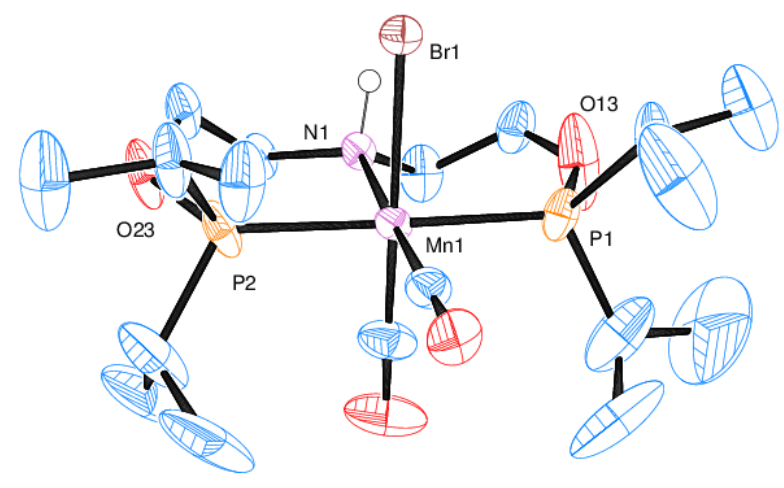

Figure 4. Perspective view of the molecular structure of complex 1c, with thermal ellipsoids drawn at $50 \%$ probability. Hydrogen atoms, except $\mathrm{N} H$, were omitted for clarity.

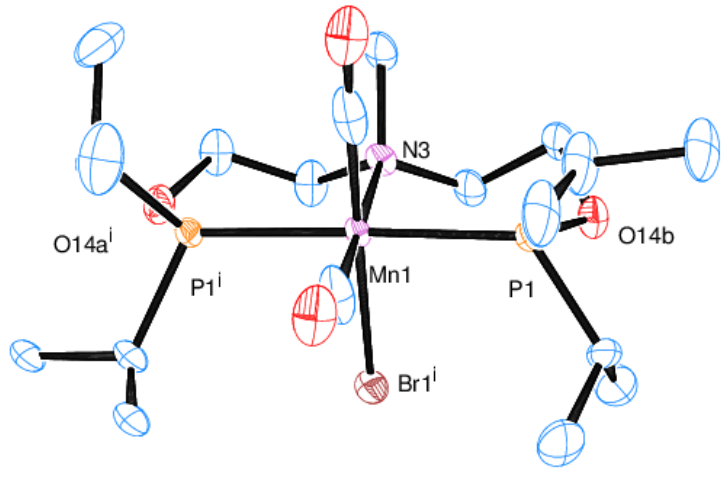

Figure 5. Perspective view of the molecular structure of complex 2c with thermal ellipsoids drawn at $50 \%$ probability. Hydrogen atoms were omitted for clarity. Two configurations of the compound are superimposed in the crystal structure, only one is depicted.

\section{Catalytic Experiments.}

With these new complexes in hand, we explored their catalytic activity in the reduction of ketones with molecular hydrogen (Table 1). Based on the optimized conditions defined for the reduction of acetophenone using complex $\mathbf{V},{ }^{23}$ initial experiments were performed on acetophenone as model substrate at $110{ }^{\circ} \mathrm{C}$, with $1 \mathrm{~mol} \%$ catalyst and $2 \mathrm{~mol} \% \mathrm{tBuOK}$ loadings. Under 30 bar of $\mathrm{H}_{2}$, (pre)catalyst $\mathbf{1 b}$ bearing a secondary amine led to a promising conversion of $87 \%$ after $20 \mathrm{~h}$ of reaction. No reaction occurred when the catalysts bear a tertiary amine such as in $\mathbf{2 b}$ and $\mathbf{3 b}$ (entries 2 and 3). This clear difference of reactivity is in line with the importance of $\mathrm{NH}$-moieties to promote hydrogenation via the "classical" cooperative ligand-metal mechanism. ${ }^{19 \mathrm{~b}-\mathrm{e}, 20 \mathrm{~b}, 26}$

At $110{ }^{\circ} \mathrm{C}$, the influence of the pressure was limited, as increasing to 50 bar or lowering to 10 bar only induced minor variations of the conversion (90 to $81 \%$, entries 4-5). On the other hand, the temperature was more crucial to reach high conversion: from $120{ }^{\circ} \mathrm{C}$ to $70{ }^{\circ} \mathrm{C}$, the conversion dropped from $98 \%$ to $38 \%$ over the $20 \mathrm{~h}$ reaction time (entries 6-8).

Interestingly, the catalyst loading could be halved down to $0.5 \mathrm{~mol} \%$ at $120{ }^{\circ} \mathrm{C}$ without apparent degradation of the activity (entry $9 v s$ entry 6), and even lowered to $0.1 \mathrm{~mol} \%(93 \%$ conv., entry 10) leading to an overall TON of $930 .^{27,28}$

It is worth noting that, with the simpler PONOP ligand, the same catalytic load of $0.5 \mathrm{~mol} \%$ can be reached with $\mathbf{1 b}$ as with complex $\mathbf{V}$ based on PNP ligand, yet at a higher temperature $\left(120^{\circ} \mathrm{C}\right.$ vs $70^{\circ} \mathrm{C}$, entry 9 vs 11$)$.

The manganese complexes were also tested, but were found to be significantly less active: only $25 \%$ conversion was obtained with $1 \mathrm{~mol} \%$ catalyst at $120{ }^{\circ} \mathrm{C}$ under 50 bar of hydrogen. Surprisingly, the $N$-Me complex $1 \mathrm{c}$ led to nearly the same conversion as the $\mathrm{NH}$ one $\mathbf{2 c}$, which suggests that the reaction with these Mn complexes may proceed via a different mechanism. ${ }^{20 b, 26}$ 
Table 1: Optimization of reaction parameters for the hydrogenation of acetophenone ${ }^{a}$

\begin{tabular}{|l|l|l|l|l|l|l|}
\hline \multicolumn{5}{|c|}{ Cat. , tBuOK } \\
\hline Entry & $\begin{array}{l}\text { Cat. } \\
(\mathrm{mol} \%)\end{array}$ & $\begin{array}{l}\mathrm{H}_{2} \\
(\mathrm{bar})\end{array}$ & $\begin{array}{l}\text { tBuOK } \\
(\mathrm{mol} \%)\end{array}$ & $\begin{array}{l}\text { Temp. } \\
\left({ }^{\circ} \mathrm{C}\right)\end{array}$ & $\begin{array}{l}\text { Time } \\
(\mathrm{h})\end{array}$ & $\begin{array}{l}\text { Conv. } \\
(\%)\end{array}$ \\
\hline 1 & $\mathbf{1 b}(1.0)$ & 30 & 2.0 & 110 & 20 & 87 \\
\hline 2 & $\mathbf{2 b}(1.0)$ & 30 & 2.0 & 110 & 20 & 2 \\
\hline 3 & $\mathbf{3 b}(1.0)$ & 30 & 2.0 & 110 & 20 & 0 \\
\hline 4 & $\mathbf{1 b}(1.0)$ & 50 & 2.0 & 110 & 20 & 90 \\
\hline 5 & $\mathbf{1 b}(1.0)$ & 10 & 2.0 & 110 & 20 & 81 \\
\hline 6 & $\mathbf{1 b}(1.0)$ & 50 & 2.0 & 120 & 20 & 98 \\
\hline 7 & $\mathbf{1 b}(1.0)$ & 50 & 2.0 & 100 & 20 & 80 \\
\hline 8 & $\mathbf{1 b}(1.0)$ & 50 & 2.0 & 70 & 20 & 38 \\
\hline 9 & $\mathbf{1 b}(0.5)$ & 50 & 1.0 & 120 & 20 & 98 \\
\hline 10 & $\mathbf{1 b}(0.1)$ & 50 & 5.0 & 120 & 20 & 93 \\
\hline 11 & $\mathbf{V}(0.5)$ & 30 & 1.0 & 70 & 16 & 98 \\
\hline 12 & $\mathbf{1 c}(1.0)$ & 50 & 2.0 & 120 & 20 & 25 \\
\hline 13 & $\mathbf{2 c}(1.0)$ & 50 & 2.0 & 120 & 20 & 20 \\
\hline
\end{tabular}

a General conditions: Under argon, an autoclave was charged with the (pre)catalyst, toluene $(1.0 \mathrm{~mL})$, followed by acetophenone $(0.25 \mathrm{mmol}, 29 \mu \mathrm{L})$ and $t \mathrm{BuOK}$, in this order. The autoclave was then charged with $\mathrm{H}_{2}$ and heated in an oil bath. ${ }^{\mathrm{b}}$ The conversion (\%) was determined by ${ }^{1} \mathrm{H}$ NMR on the crude reaction mixture.

With the optimized conditions in hand (Table 1, entry 9), we probed the generality of the reaction (Table 2). In general, from regular aromatic ketones (4a-15a), the corresponding alcohols (4b-15b) were obtained in good to high yields with both electron-donating and electron-withdrawing substituents. The reactivity was noticeably affected by steric hindrance in the $\alpha$-position to the carbonyl group, as isobutyrophenone and cyclopropylphenylketone (17a-18a) were very slowly or not reduced, respectively, under standard conditions. Cyano or nitro group at the para position of the aromatic ring also inhibited the reaction. This lack of reactivity might be attributed to the weak, yet competitive coordination abilities toward the catalyst of such functional group. Additionally, heteroaromatic substrates based on thiophene (19a) and pyridine (20a) were smoothly reduced. Not unexpectedly, aliphatic, cyclic and diaryl ketones (21a-26a) required slightly harsher conditions to be hydrogenated. Most interestingly, the reaction is chemoselective towards $\mathrm{C}=\mathrm{O}$, as the remote trisubtituted $\mathrm{C}=\mathrm{C}$

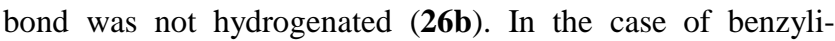
deneacetone, as a model of $\alpha, \beta$-unsaturated ketones, the starting material was fully converted into a mixture of corresponding unsaturated alcohol $(27 \%)$ and saturated alcohol $(24 \%)$ along with the saturated ketone $(49 \%)$ as the major product.
Table 2. Scope of the hydrogenation of ketones to give alcohols under the catalysis of $\mathbf{1 b}^{\mathrm{a}}$

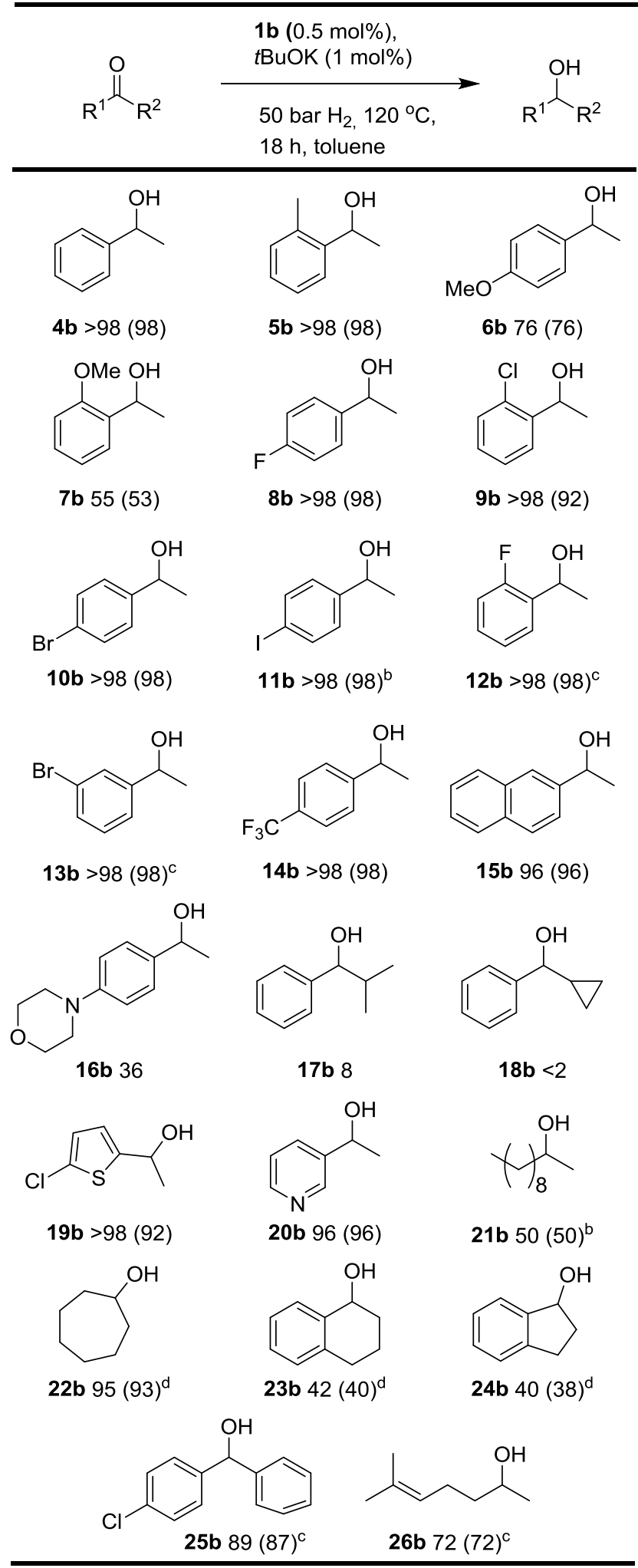

a General conditions: Under argon, an autoclave was charged with complex $1 \mathbf{b}(0.5 \mathrm{~mol} \%)$, toluene $(2.0 \mathrm{~mL})$, followed by ketone $(2 \mathrm{mmol})$ and $t \mathrm{BuOK}(1.0 \mathrm{~mol} \%)$, in this order. The autoclave was then charged with $\mathrm{H}_{2}$ (50 bar). The mixture was stirred for $18 \mathrm{~h}$ at $120{ }^{\circ} \mathrm{C}$ in an oil bath. The conversion (\%) was determined by ${ }^{1} \mathrm{H}$ NMR on the crude reaction mixture. Isolated yields $(\%)$ are provided in parentheses. ${ }^{\mathrm{b}} \mathbf{1 b}(1.0 \mathrm{~mol} \%), t \mathrm{BuOK}(2.0$ 


\section{Mechanistic investigations.}

In order to get more insights into the operative mechanism of this rhenium-catalyzed hydrogenation, a series of experiments in Young-type NMR tubes was conducted (Scheme 3) and followed by ${ }^{31} \mathrm{P}$ NMR spectroscopy (Figure 6). First, complex $\mathbf{1 b}\left(\delta\left({ }^{31} \mathrm{P}\left\{{ }^{1} \mathrm{H}\right\}\right)=128.8 \mathrm{ppm}\right)$ reacted with KHMDS (2.0 equiv.) in toluene- $d_{8}$ (the reaction proved more selective with 2 equiv than 1 equiv; see Figure S82, S.I.). The complex was fully converted at room temperature within short time (typically $1 \mathrm{~h}$ ) into a new species (1d) displaying a single singlet at $\delta 156.1 \mathrm{ppm}$. The ${ }^{1} \mathrm{H}$ NMR spectrum was consistent with a highly symmetrical species. Even if single crystals of compound 1d suitable for X-ray diffraction studies could not be obtained, one can reasonably assume that the structure of $\mathbf{1 d}$, resulting from the deprotonation of $\mathbf{1 b}$ with the base, is likely to be a neutral dicarbonyl complex with an amidoligand. ${ }^{\text {aa, }}{ }^{29}$ Upon addition of $\mathrm{H}_{2}$ (2 bar) inside the NMR tube, complex $1 \mathrm{~d}$ reacted slowly at room temperature overnight (or in $1 \mathrm{~h}$ at $120{ }^{\circ} \mathrm{C}$, see Figures S83-S84, S.I.) to afford two rhenium hydride species, 1e' and $\mathbf{1 e}$ ", in a ratio $2: 5$, exhibiting typical signals in NMR $\left(1 \mathbf{e}^{\prime} \delta\left({ }^{31} \mathrm{P}\left\{{ }^{1} \mathrm{H}\right\}\right)=157.8 \mathrm{ppm}, \delta\left({ }^{1} \mathrm{H}\right)=\right.$ $-2.45 \mathrm{ppm}(\mathrm{t}, J=25.9 \mathrm{~Hz}), \mathbf{1 e}$ " $\delta\left({ }^{31} \mathrm{P}\left\{{ }^{1} \mathrm{H}\right\}\right)=153.5 \mathrm{ppm}, \delta\left({ }^{1} \mathrm{H}\right)$ $=-2.07 \mathrm{ppm}(\mathrm{t}, J=28.8 \mathrm{~Hz}))$. The two hydride complexes probably correspond to isomers, the $\mathrm{Re}-\mathrm{H}$ bond being presumably either syn or anti to the $N-\mathrm{H}$ one. ${ }^{10 \mathrm{a}, 29 \mathrm{c}, 30}$

After releasing the $\mathrm{H}_{2}$ pressure, acetophenone (1.0 equiv.) was charged in the NMR tube. After $18 \mathrm{~h}$ at $120^{\circ} \mathrm{C}$, the signals of 1e' and 1e" disappeared, while concomitantly the characteristic signal of $\mathbf{1 d}$ reappeared. In the ${ }^{1} \mathrm{H}$ NMR spectrum, the signal of acetophenone also disappeared. Yet, the formation of 1-phenylethanol, resulting from the transfer of the two protons from 1e to the ketone, could not be detected, likely as it reacted with excess KHMDS to form an alkoxide salt insoluble in toluene (Note that at the end of the series of reactions, upon addition of $\mathrm{H}_{2} \mathrm{O}$, the characteristic signals of 1phenylethanol were eventually observed). Finally, rhenium hydride complexes were regenerated by pressurizing again the NMR tube under $\mathrm{H}_{2}$ and heating. Interestingly, after 3 days, a slow isomerization took place, leading exclusively to $\mathbf{1} \mathbf{e}$.

\section{Scheme 3: Stoichiometric reactions}

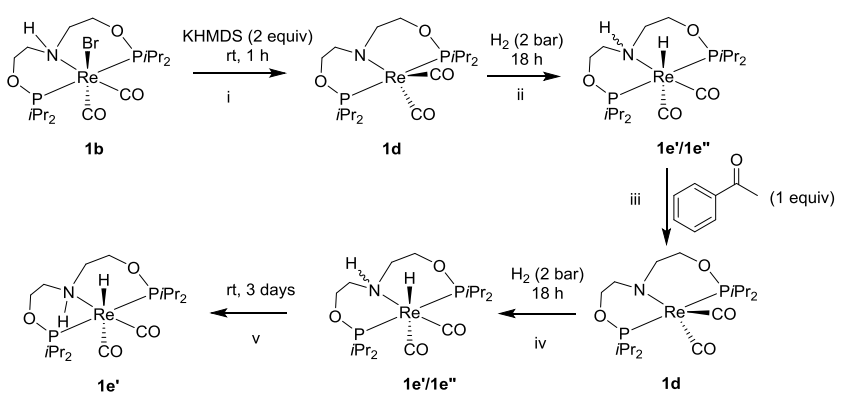

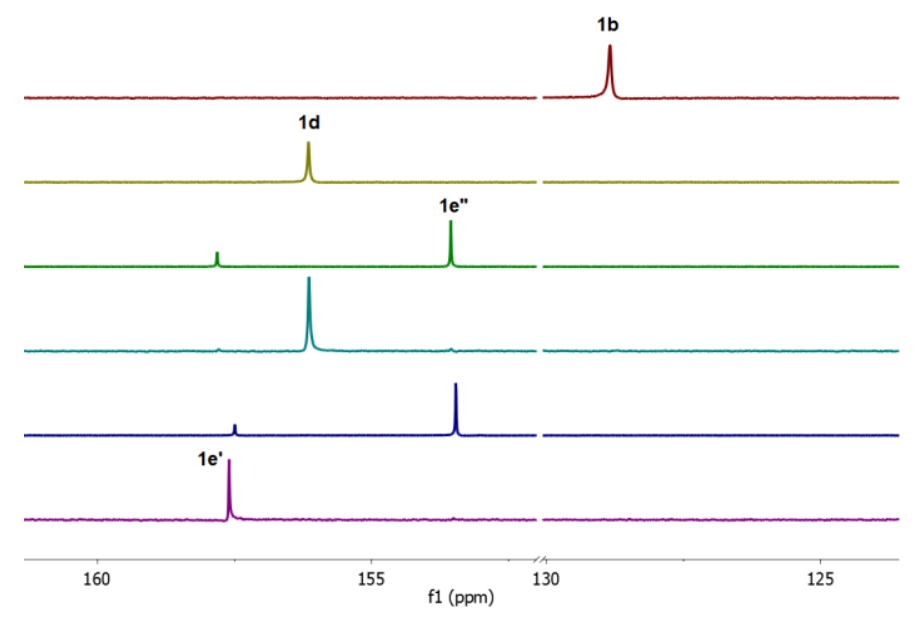

Figure 6. Monitoring of the stoichiometric reactions described on Scheme 3 by ${ }^{31} \mathrm{P}\left\{{ }^{1} \mathrm{H}\right\}$ NMR spectroscopy, starting from $\mathbf{1 b}$ (top), to $1 \mathrm{e}^{\prime}$ (bottom), via the reaction steps $i$ to $v$.

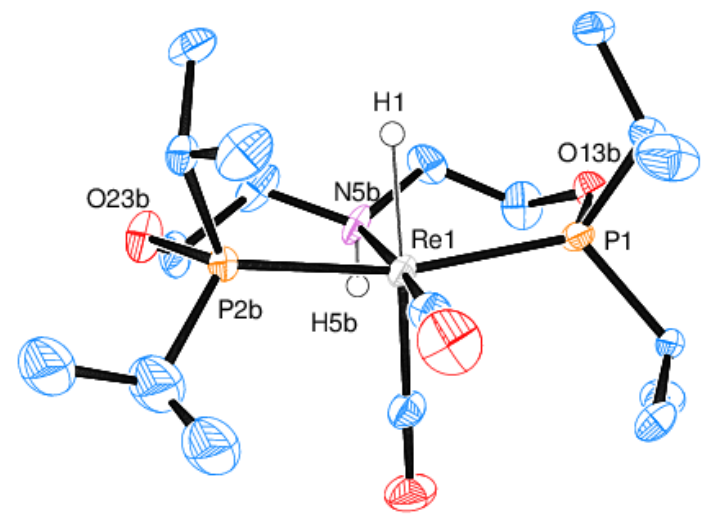

Figure 7. Perspective view of the molecular structure of complex 1e', with thermal ellipsoids drawn at $50 \%$ probability. Hydrogen atoms, except $\mathrm{N} H$ and hydride, were omitted for clarity.

Single crystals suitable for X-ray diffraction studies were obtained for the rhenium hydride complex and revealed the $\mathrm{Re}-\mathrm{H}$ and $\mathrm{N}-\mathrm{H}$ bonds in anti position (Figure 7). We assume that this isomer corresponds to the more stable one, and we therefore assigned it as 1e'. 1e", with the two protons in a synconfiguration would be the active catalytic species. ${ }^{10 a}$ The epimerization of the $\mathrm{N}-\mathrm{H}$ bond is likely to occur in the presence of base or traces of alcohol.

Finally, having identified the NMR signature of the rhenium-hydride complexes, the integrity of the catalyst after a catalytic run was also confirmed, by running in an autoclave the hydrogenation of acetophenone with $20 \mathrm{~mol} \%$ of $\mathbf{1 b}$ (and $40 \mathrm{~mol} \%$ of $t \mathrm{BuOK}$ ) in toluene- $d_{8}$ at $110{ }^{\circ} \mathrm{C}$ for $3 \mathrm{~h}$ and by 
analyzing the crude reaction mixture by NMR; this revealed

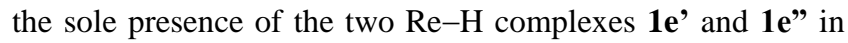
the ${ }^{31} \mathrm{P}\left\{{ }^{1} \mathrm{H}\right\}$ NMR spectrum (see Figures S80-81).

\section{CONCLUSION}

In conclusion, five new complexes based on easily accessible and easily tunable amino-bisphosphinite ligands have been prepared and fully characterized. Rhenium complex 1b, displaying metal-ligand cooperation, is an efficient catalyst for the hydrogenation of ketones. The reaction proceeds at $120^{\circ} \mathrm{C}$ with the same catalyst load as the less affordable aminobisphosphine rhenium catalyst $\mathbf{V}$ (chart 1). Interestingly, the reaction could be monitored stepwise by NMR and a rhenium hydride was isolated and crystallized.

\section{EXPERIMENTAL SECTION}

General Methods. All reactions were carried out with oven-dried glassware using standard Schlenk techniques under an inert atmosphere of dry argon or in an argon-filled glove-box. Toluene, THF, diethyl ether $\left(\mathrm{Et}_{2} \mathrm{O}\right)$, and $\mathrm{CH}_{2} \mathrm{Cl}_{2}$ were dried over MBraun MB-SPS800 solvent purification system and degassed by thaw-freeze cycles. Technical grade pentane and diethyl ether were used for column chromatography. Analytical TLC was performed on Merck $60 \mathrm{~F}_{254}$ silica gel plates $(0.25 \mathrm{~mm}$ thickness). Column chromatography was performed on Acros Organics Ultrapure silica gel (mesh size 40-60 $\mu \mathrm{m}, 60 \AA$ ). All reagents were obtained from commercial sources and liquid reagents were dried on molecular sieves and degassed prior to use. Rhenium pentacarbonyl bromide, $98 \%$, and manganese pentacarbonyl bromide, min $98 \%$, were purchased from Strem Chemicals.

${ }^{1} \mathrm{H}$ and ${ }^{13} \mathrm{C}\left\{{ }^{1} \mathrm{H}\right\}$ NMR spectra were recorded in $\mathrm{CDCl}_{3}, \mathrm{CD}_{2} \mathrm{Cl}_{2}$, $\mathrm{C}_{6} \mathrm{D}_{6}$ or toluene- $d_{8}$ at ambient temperature unless otherwise stated, on Bruker AVANCE 500, AVANCE 400 and AVANCE 300 spectrometers at 500, 400 and $300 \mathrm{MHz}$, respectively. ${ }^{1} \mathrm{H}$ and ${ }^{13} \mathrm{C}$ spectra were calibrated using the residual solvent signal as internal standard $\left({ }^{1} \mathrm{H}\right.$ : $\mathrm{CDCl}_{3} 7.26 \mathrm{ppm}, \mathrm{CD}_{2} \mathrm{Cl}_{2} 5.32 \mathrm{ppm}, \mathrm{C}_{6} \mathrm{D}_{6} 7.16 \mathrm{ppm}$, toluene- $d_{8} 2.08$ ppm, ${ }^{13} \mathrm{C}: \mathrm{CDCl}_{3} 77.16$ ppm, $\mathrm{CD}_{2} \mathrm{Cl}_{2} 53.84 \mathrm{ppm}$, toluene- $d_{8} 20.43$ ppm, $\left.\mathrm{C}_{6} \mathrm{D}_{6} 128.06 \mathrm{ppm}\right)$. IR spectra were measured by Shimadzu IRAffinity 1 with ATR equipment or in solution. HR-MS spectra and microanalyses were carried out by the corresponding facilities at the CRMPO (Centre Régional de Mesures Physiques de l'Ouest), University of Rennes 1.

X-ray diffraction data were collected on D8 VENTURE Bruker AXS diffractometer equipped with a PHOTON 100 CMOS detector, using multilayers monochromated Mo-K $\alpha$ radiation $(\lambda=0.71073 \AA)$ at $\mathrm{T}=150 \mathrm{~K}$. X-Ray data are summarized in the Supporting Information.

Ligands 1a-3a were prepared following literature procedures. ${ }^{22}$

Synthesis of complexes

Complex $\quad \mathbf{l b}$. Representative procedure. Bis(2((diisopropylphosphino)oxy)ethyl)amine 1a $(0.240 \mathrm{mmol}, 80.9 \mathrm{mg}$, 1.0 equiv.) was added to a solution of $\operatorname{Re}(\mathrm{CO})_{5} \mathrm{Br}(0.240 \mathrm{mmol}, 97.5$ $\mathrm{mg}, 1.0$ equiv.) in anhydrous toluene $(2 \mathrm{~mL})$. The mixture was stirred at $100{ }^{\circ} \mathrm{C}$ overnight. Toluene was then evaporated. The crude residue was then recrystallized from dichloromethane $(1 \mathrm{~mL})$ and pentane $(5$ $\mathrm{mL}$ ) to afford white flake crystals. The white solid was washed with pentane $(2 \times 2 \mathrm{~mL})$ to afford pure compound $(146.5 \mathrm{mg}, 93 \%)$. Single crystals suitable for $\mathrm{X}$-Ray diffraction studies were grown by slow diffusion of pentane into a $\mathrm{CH}_{2} \mathrm{Cl}_{2}$ solution of $\mathbf{1 b}$ at r.t.

${ }^{1} \mathrm{H}$ NMR $\left(400 \mathrm{MHz}, \mathrm{CD}_{2} \mathrm{Cl}_{2}\right) \delta 4.22-4.01\left(\mathrm{~m}, 4 \mathrm{H}, \mathrm{N}-\mathrm{CH}_{2}\right), 3.46-$ $3.28\left(\mathrm{~m}, 2 \mathrm{H}, \mathrm{CH}_{i \mathrm{Pr}}\right), 3.23-3.09\left(\mathrm{~m}, 2 \mathrm{H}, \mathrm{O}-\mathrm{CH}_{2}\right), 3.08-2.98(\mathrm{~m}, 2 \mathrm{H}$, $\left.\mathrm{O}-\mathrm{CH}_{2}\right), 2.81-2.58\left(\mathrm{~m}, 2 \mathrm{H}, \mathrm{CH}_{i \mathrm{Pr}}\right), 1.40-1.13\left(\mathrm{~m}, 24 \mathrm{H}, \mathrm{CH}_{3 i \mathrm{Pr}}\right)$. (Note : the $\mathrm{NH}$ proton was not observed in the spectrum)

${ }^{31} \mathrm{P}\left\{{ }^{1} \mathrm{H}\right\}$ NMR $\left(162 \mathrm{MHz}, \mathrm{CD}_{2} \mathrm{Cl}_{2}\right) \delta 128.8$.
${ }^{13} \mathrm{C}\left\{{ }^{1} \mathrm{H}\right\}$ NMR (101 MHz, $\left.\mathrm{CD}_{2} \mathrm{Cl}_{2}\right) \delta 202.0$ (br., CO), 197.2 (br., $\mathrm{CO}), 66.19\left(\mathrm{~N}-\mathrm{CH}_{2}\right), 58.75\left(\mathrm{t}, J=3.4 \mathrm{~Hz}, \mathrm{O}-\mathrm{CH}_{2}\right), 31.76(\mathrm{t}, J=17.9$ $\left.\mathrm{Hz}, C H_{i \mathrm{Pr}}\right), 29.55\left(\mathrm{t}, J=11.6 \mathrm{~Hz}, C_{i \mathrm{Pr}}\right), 18.92\left(\mathrm{t}, J=2.7 \mathrm{~Hz}, C H_{3 i \mathrm{Pr}}\right)$, $18.33\left(\mathrm{CH}_{3 \mathrm{iPr}}\right), 17.81\left(\mathrm{t}, J=2.1 \mathrm{~Hz}, \mathrm{CH}_{3 i \mathrm{Pr}}\right), 16.43\left(\mathrm{CH}_{3 \mathrm{iPr}}\right)$.

Anal. Calc (\%). for $\left(\mathrm{C}_{18} \mathrm{H}_{37} \mathrm{NO}_{4} \mathrm{BrP}_{2} \mathrm{Re}\right)$ : C, 32.78; H, 5.65; N, 2.12. Found: C, 32.53; H, 5.60; N, 2.06.

HR MS (ESI): $\mathrm{m} / \mathrm{z}[\mathrm{M}+\mathrm{Na}]^{+}$calcd for $\mathrm{C}_{18} \mathrm{H}_{37} \mathrm{NO}_{4}{ }^{79} \mathrm{BrNaP}_{2}{ }^{187} \mathrm{Re}$ 682.0831, found $682.0824(1 \mathrm{ppm}) ; \mathrm{m} / \mathrm{z} \quad[\mathrm{M}-. \mathrm{Br}]^{+}$calcd for $\mathrm{C}_{18} \mathrm{H}_{37} \mathrm{NO}_{4} \mathrm{P}_{2}{ }^{187} \mathrm{Re} 580.1755$, found $580.1749(0 \mathrm{ppm})$

IR ( $\left(v, \mathrm{~cm}^{-1}, \mathrm{CH}_{2} \mathrm{Cl}_{2}\right): 1929,1840$.

Complex $2 \boldsymbol{b}$. Following the same procedure as for the synthesis of complex 1b, starting from $\mathbf{2 a}(100.0 \mathrm{mg}, 0.284 \mathrm{mmol})$ and $\operatorname{Re}(\mathrm{CO})_{5} \mathrm{Br}$ (115.6 $\mathrm{mg}, 0.284 \mathrm{mmol}$ ), complex $\mathbf{2 b}$ was obtained as a white solid (174.6 mg, 92\%).

${ }^{1} \mathrm{H}$ NMR $\left(400 \mathrm{MHz}, \mathrm{CD}_{2} \mathrm{Cl}_{2}\right) \delta 4.46-4.33\left(\mathrm{~m}, 2 \mathrm{H}, \mathrm{N}-\mathrm{CH}_{2}\right), 4.33-$ $4.21\left(\mathrm{~m}, 2 \mathrm{H}, \mathrm{O}-\mathrm{CH}_{2}\right), 4.14-3.97\left(\mathrm{~m}, 2 \mathrm{H}, \mathrm{N}-\mathrm{CH}_{2}\right), 3.40-3.27(\mathrm{~m}$, $\left.2 \mathrm{H}, \mathrm{CH}_{i \mathrm{Pr}}\right), 3.01\left(\mathrm{~s}, 3 \mathrm{H}, \mathrm{N}-\mathrm{CH}_{3}\right), 2.87-2.72\left(\mathrm{~m}, 2 \mathrm{H}, \mathrm{CH}_{i \mathrm{Pr}}\right), 1.96(\mathrm{dd}$, $\left.J=13.6,3.8 \mathrm{~Hz}, 2 \mathrm{H}, \mathrm{O}-\mathrm{CH}_{2}\right), 1.39-1.14\left(\mathrm{~m}, 24 \mathrm{H}, \mathrm{CH}_{3 i \mathrm{Pr}}\right)$.

${ }^{13} \mathrm{C}\left\{{ }^{1} \mathrm{H}\right\}$ NMR (101 MHz, $\left.\mathrm{CD}_{2} \mathrm{Cl}_{2}\right) \delta 199.8$ (br., CO), 198.4 (br. $\mathrm{CO}), 64.0\left(\mathrm{~N}-\mathrm{CH}_{2}\right), 63.2\left(\mathrm{t}, \mathrm{J}=3 \mathrm{~Hz}, \mathrm{O}-\mathrm{CH}_{2}\right), 50.7\left(\mathrm{~N}-\mathrm{CH}_{3}\right), 32.7$ (t, $\left.J=13 \mathrm{~Hz}, C H_{i \mathrm{Pr}}\right), 31.6\left(\mathrm{t}, J=17 \mathrm{~Hz}, C H_{i \mathrm{Pr}}\right), 18.5\left(\mathrm{t}, J=2 \mathrm{~Hz}, C H_{3 i \mathrm{Pr}}\right)$, $18.2\left(\mathrm{t}, J=2 \mathrm{~Hz}, \mathrm{CH}_{3 \mathrm{iPr}}\right), 18.0\left(\mathrm{CH}_{3 \mathrm{iPr}}\right), 17.2\left(\mathrm{CH}_{3 \mathrm{iPr}}\right)$.

${ }^{31} \mathrm{P}\left\{{ }^{1} \mathrm{H}\right\} \mathrm{NMR}\left(162 \mathrm{MHz}, \mathrm{CD}_{2} \mathrm{Cl}_{2}\right) \delta 129.4$.

Anal. Calc (\%). for $\left(\mathrm{C}_{19} \mathrm{H}_{39} \mathrm{NO}_{4} \mathrm{BrP}_{2} \mathrm{Re}\right)$ : C, 33.88; H, 5.84; N, 2.08, Found: C, 33.84; H, 5.94; N, 2.16 .

HR-MS (ESI): $\mathrm{m} / \mathrm{z}[\mathrm{M}+\mathrm{Na}]^{+}$calcd for $\mathrm{C}_{19} \mathrm{H}_{39} \mathrm{NO}_{4}{ }^{79} \mathrm{BrNaP}_{2}{ }^{187} \mathrm{Re}$ 696.0993, found $696.0983(1 \mathrm{ppm}) ; \mathrm{m} / \mathrm{z} \quad[\mathrm{M}+\mathrm{K}]^{+}$calcd for $\mathrm{C}_{19} \mathrm{H}_{39} \mathrm{NO}_{4}{ }^{79} \mathrm{BrKP}_{2}{ }^{187} \mathrm{Re}$ 712.07269, found 712.0714 (2 ppm)

IR ( $\left.v, \mathrm{~cm}^{-1}, \mathrm{CH}_{2} \mathrm{Cl}_{2}\right): 1925,1834$.

IR ( $\left.v, \mathrm{~cm}^{-1}, \mathrm{ATR}\right): 1911,1822$

Complex $3 \boldsymbol{b}$. Following the same procedure as for the synthesis of complex 1b, starting from 3a (100.0 mg, $0.234 \mathrm{mmol})$ and $\mathrm{Re}(\mathrm{CO})_{5} \mathrm{Br}$ (95.0 $\mathrm{mg}, 0.234 \mathrm{mmol})$, complex $\mathbf{3 b}$ was obtained as a white solid (163.6 mg, 93\%).

${ }^{1} \mathrm{H}$ NMR $\left(400 \mathrm{MHz}, \mathrm{CD}_{2} \mathrm{Cl}_{2}\right) \delta 7.43-7.27\left(\mathrm{~m}, 3 \mathrm{H}, \mathrm{H}_{\mathrm{Ar}}\right), 7.07-7.02$ $\left(\mathrm{m}, 2 \mathrm{H}, \mathrm{H}_{\mathrm{Ar}}\right), 4.82\left(\mathrm{~s}, 2 \mathrm{H}, \mathrm{CH}_{2}-\mathrm{C}_{6} \mathrm{H}_{6}\right), 4.75-4.57\left(\mathrm{~m}, 2 \mathrm{H}, \mathrm{N}-\mathrm{CH}_{2}\right)$, $4.21-4.01\left(\mathrm{~m}, 2 \mathrm{H}, \mathrm{N}-\mathrm{CH}_{2}\right), 3.86\left(\mathrm{dd}, \mathrm{J}=13.5,9.8 \mathrm{~Hz}, 2 \mathrm{H}, \mathrm{O}-\mathrm{CH}_{2}\right)$, 3.40 (dhept, $\left.J=14.1,7.1 \mathrm{~Hz}, 2 \mathrm{H}, C_{i \mathrm{Pr}}\right), 2.96-2.81\left(\mathrm{~m}, 2 \mathrm{H}, C \mathrm{CH}_{\mathrm{PPr}}\right)$, $2.25\left(\mathrm{dd}, J=14.3,4.9 \mathrm{~Hz}, 2 \mathrm{H}, \mathrm{O}-\mathrm{CH}_{2}\right), 1.58-1.13\left(\mathrm{~m}, 24 \mathrm{H}, \mathrm{CH}_{3 i \mathrm{Pr}}\right)$.

${ }^{31} \mathrm{P}\left\{{ }^{1} \mathrm{H}\right\} \mathrm{NMR}\left(162 \mathrm{MHz}, \mathrm{CD}_{2} \mathrm{Cl}_{2}\right) \delta 131.0$.

${ }^{13} \mathrm{C}\left\{{ }^{1} \mathrm{H}\right\}$ NMR $\left(101 \mathrm{MHz}, \mathrm{CD}_{2} \mathrm{Cl}_{2}\right) \delta 199.6$ (br. t, $\left.J=7 \mathrm{~Hz}, \mathrm{CO}\right)$, 198.7 (br. t, $J=7 \mathrm{~Hz}, \mathrm{CO}), 132.1\left(\mathrm{C}_{\mathrm{Ar}}\right), 129.09\left(\mathrm{C}_{\mathrm{Ar}}\right), 129.06\left(\mathrm{C}_{\mathrm{Ar}}\right)$, 64.0( $\left.\mathrm{N}-\mathrm{CH}_{2}\right), 61.4\left(\mathrm{CH}_{2}-\mathrm{C}_{6} \mathrm{H}_{6}\right), 56.1\left(\mathrm{t}, J=2 \mathrm{~Hz}, \mathrm{O}-\mathrm{CH}_{2}\right), 33.0(\mathrm{t}, J=$ $\left.12 \mathrm{~Hz}, C H_{i \mathrm{Pr}}\right), 31.7\left(\mathrm{t}, J=17 \mathrm{~Hz}, C H_{i \mathrm{Pr}}\right), 18.7\left(\mathrm{t}, J=2 \mathrm{~Hz}, C H_{3 i \mathrm{Pr}}\right)$, $18.11\left(\mathrm{CH}_{3 i \mathrm{Pr}}\right), 18.06\left(\mathrm{t}, \mathrm{J}=2 \mathrm{~Hz}, \mathrm{CH}_{3 \mathrm{Pr}}\right), 17.5\left(\mathrm{CH}_{3 i \mathrm{Pr}}\right)$.

Anal. Calc (\%). for $\left(\mathrm{C}_{25} \mathrm{H}_{43} \mathrm{NO}_{4} \mathrm{BrP}_{2} \mathrm{Re}\right)$ : C, 40.05; H, 5.78; N, 1.87, Found: C, 39.77; H, 5.88; N, 1.87 .

HR-MS (ESI): $\mathrm{m} / \mathrm{z} \quad[\mathrm{M}]^{+}$calcd for $\mathrm{C}_{25} \mathrm{H}_{43} \mathrm{NO}_{4}{ }^{79} \mathrm{BrP}_{2}{ }^{187} \mathrm{Re}$ 749.1408 , found $749.1391(2 \mathrm{ppm})$

IR $\left(v, \mathrm{~cm}^{-1}, \mathrm{CH}_{2} \mathrm{Cl}_{2}\right): 1925,1834$.

IR ( $v, \mathrm{~cm}^{-1}$, ATR): 1932, 1832.

Complex 1c. Following the same procedure as for the synthesis of complex 1b, starting from 1a $(100.0 \mathrm{mg}, 0.296 \mathrm{mmol})$ and $\mathrm{Mn}(\mathrm{CO})_{5} \mathrm{Br}(81.4 \mathrm{mg}, 0.296 \mathrm{mmol})$, complex 1c was obtained as an orange solid (129.5 mg, $82 \%$ )

${ }^{1} \mathrm{H}$ NMR (400 MHz, $\left.\mathrm{CD}_{2} \mathrm{Cl}_{2}\right) \delta 4.30-3.85\left(\mathrm{~m}, 4 \mathrm{H}, \mathrm{CH}_{2}\right), 3.66-$ $3.32\left(\mathrm{~m}, 2 \mathrm{H}, C \mathrm{H}_{\mathrm{iPr}}\right), 3.24-2.92\left(\mathrm{~m}, 3 \mathrm{H}, \mathrm{NH}+\mathrm{CH}_{2}\right), 2.81(\mathrm{dd}, J=$ $\left.10.4,3.1 \mathrm{~Hz}, 2 \mathrm{H}, \mathrm{CH}_{2}\right), 2.75-2.62\left(\mathrm{~m}, 2 \mathrm{H}, \mathrm{CH}_{\mathrm{PPr}}\right), 1.47-1.14(\mathrm{~m}$, $24 \mathrm{H}, \mathrm{CH}_{3 \mathrm{iPr}}$.

${ }^{13} \mathrm{C}\left\{{ }^{1} \mathrm{H}\right\}$ NMR $\left(101 \mathrm{MHz}, \mathrm{CD}_{2} \mathrm{Cl}_{2}\right) \delta 64.8\left(\mathrm{CH}_{2}\right), 57.4$ (br., $\left.\mathrm{CH}_{2}\right)$, 31.4-31.1 (m, 2C, $\mathrm{CH}_{i \mathrm{Pr}}$ ), 18.3 (br., $\left.\mathrm{CH}_{3 i \mathrm{Pr}}\right), 17.9$ ( $\left.\mathrm{CH}_{3 i \mathrm{Pr}}\right), 17.6$ (br., $\mathrm{CH}_{3 i \mathrm{Pr}}$ ), 16.5 (br., $\mathrm{CH}_{3 \mathrm{iPr}}$ ). (CO signals not detected)

${ }^{31} \mathrm{P}\left\{{ }^{1} \mathrm{H}\right\}$ NMR $\left(162 \mathrm{MHz}, \mathrm{CD}_{2} \mathrm{Cl}_{2}\right) \delta 174.7$.

Anal. Calc (\%). for $\left(\mathrm{C}_{18} \mathrm{H}_{37} \mathrm{NO}_{4} \mathrm{BrP}_{2} \mathrm{Mn}\right)$ : C, 40.92; H, 7.06; N, 2.65, Found: C, 40.82; H, 6.73; N, 2.42 . 
HR-MS (ESI): $\mathrm{m} / \mathrm{z}[\mathrm{M}]^{+\cdot}$ calcd for $\mathrm{C}_{18} \mathrm{H}_{37} \mathrm{NO}_{4}{ }^{79} \mathrm{BrP}_{2} \mathrm{Mn}$ 527.0756, found $527.0754 \quad(0 \quad \mathrm{ppm}) ; \mathrm{m} / \mathrm{z} \quad[\mathrm{M}-.2 \mathrm{CO}]^{+}$calcd for $\mathrm{C}_{16} \mathrm{H}_{37} \mathrm{NO}_{2}{ }^{79} \mathrm{BrP}_{2} \mathrm{Mn} 471.08579$, found 471.0854 (1 ppm)

IR $\left(v, \mathrm{~cm}^{-1}, \mathrm{CH}_{2} \mathrm{Cl}_{2}\right): 1953,1927,1846 .{ }^{31}$

Complex 2c. Following the same procedure as for the synthesis of complex 1b, starting from $\mathbf{2 a}(100.0 \mathrm{mg}, 0.284 \mathrm{mmol})$ and $\mathrm{Mn}(\mathrm{CO})_{5} \mathrm{Br}(78.1 \mathrm{mg}, 0.284 \mathrm{mmol})$, complex $2 \mathrm{c}$ was obtained as an orange solid (124.0 mg, $80 \%)$.

${ }^{1} \mathrm{H}$ NMR (400 MHz, $\mathrm{CD}_{2} \mathrm{Cl}_{2}$ ) $\delta 4.41-4.25$ (br. s, $2 \mathrm{H}, \mathrm{CH}_{2}$ ), $4.11-$ 3.80 (br., $4 \mathrm{H}, \mathrm{CH}_{2}$ ), 3.53-3.38 (br., $2 \mathrm{H}, \mathrm{CH}_{i \mathrm{Pr}}$ ), 2.91-2.73 (br., $5 \mathrm{H}$, $\mathrm{CH}_{i \mathrm{Pr}}+\mathrm{N}-\mathrm{CH}_{3}$ ), 1.72-1.61 (br., $2 \mathrm{H}, \mathrm{CH}_{2}$ ), 1.50-1.19 (br. m, $24 \mathrm{H}$, $\mathrm{CH}_{3 i \mathrm{Pr}}$.

${ }^{13} \mathrm{C}\left\{{ }^{1} \mathrm{H}\right\}$ NMR $\left(75 \mathrm{MHz}, \mathrm{CD}_{2} \mathrm{Cl}_{2}\right) \delta 61.4\left(\mathrm{CH}_{2}\right), 61.3\left(\mathrm{CH}_{2}\right), 46.9$ $\left(\mathrm{N}-\mathrm{CH}_{3}\right), 31.5-31.1\left(\mathrm{~m}, 2 \mathrm{C}, \mathrm{CH}_{i \mathrm{Pr}}\right), 17.4\left(\mathrm{CH}_{3 i \mathrm{Pr}}\right), 16.8\left(\mathrm{CH}_{3 i \mathrm{Pr}}\right), 16.5$ $\left(\mathrm{CH}_{3 \mathrm{PPr}}\right), 16.4\left(\mathrm{CH}_{3 \mathrm{PPr}}\right)$. $(\mathrm{CO}$ signals not detected $)$

${ }^{31} \mathrm{P}\left\{{ }^{1} \mathrm{H}\right\}$ NMR $\left(162 \mathrm{MHz}, \mathrm{CD}_{2} \mathrm{Cl}_{2}\right) \delta 172.2$.

Anal. Calc (\%). for $\left(\mathrm{C}_{19} \mathrm{H}_{39} \mathrm{NO}_{4} \mathrm{BrP}_{2} \mathrm{Mn}\right) .\left(\mathrm{CH}_{2} \mathrm{Cl}_{2}\right): \mathrm{C}, 38.30 ; \mathrm{H}$, 6.59 ; N, 2.23, Found: C, 38.21; H, 6.48; N, 2.88 .

HR-MS (ESI): $\mathrm{m} / \mathrm{z}$ [M-Br] ${ }^{+}$calcd for $\mathrm{C}_{19} \mathrm{H}_{39} \mathrm{NO}_{4} \mathrm{P}_{2} \mathrm{Mn} 462.1729$, found 462.1737 (2 ppm);m/z [M] $]^{+}$calcd for $\mathrm{C}_{19} \mathrm{H}_{39} \mathrm{NO}_{4}{ }^{79} \mathrm{BrP}_{2} \mathrm{Mn}$ 541.09127, found 541.0912 (0 ppm); m/z [M-.2CO $]^{+}$calcd for $\mathrm{C}_{17} \mathrm{H}_{39} \mathrm{NO}_{2}{ }^{79} \mathrm{Br} \mathrm{P} \mathrm{P}_{2} \mathrm{Mn} 485.10144$, found 485.1015 (0 ppm)

IR $\left(v, \mathrm{~cm}^{-1}, \mathrm{CH}_{2} \mathrm{Cl}_{2}\right): 1946,1923,1842 .{ }^{29}$

NMR scale synthesis of complex 1 d. In a Young-type NMR tube, complex $1 \mathbf{b}(8.4 \mathrm{mg}, 0.012 \mathrm{mmol})$ was added to a solution of KHMDS ( $4.8 \mathrm{mg}, 0.024 \mathrm{mmol})$ in dry toluene- $d_{8}(\mathrm{ca} .0 .5 \mathrm{~mL})$ at room temperature. NMR spectra were recorded after $1 \mathrm{~h}$ of reaction.

${ }^{1} \mathrm{H}$ NMR (400 MHz, $\left.\mathrm{C}_{7} \mathrm{D}_{8}\right) \delta$ 3.77-3.68 (br. m, 4H, $\mathrm{CH}_{2}$ ), 2.45 (br s, $\left.4 \mathrm{H}, \mathrm{CH}_{2}\right), 2.30-2.21\left(\mathrm{~m}, 4 \mathrm{H}, \mathrm{CH}_{\mathrm{iPr}}\right), 1.25-1.11\left(\mathrm{~m}, 24 \mathrm{H}, \mathrm{CH}_{3 \mathrm{iPr}}\right)$.

${ }^{31} \mathrm{P}\left\{{ }^{1} \mathrm{H}\right\}$ NMR $\left(162 \mathrm{MHz}_{7} \mathrm{D}_{8}\right) \delta 156.1$.

${ }^{13} \mathrm{C}\left\{{ }^{1} \mathrm{H}\right\}\left(101 \mathrm{MHz}, \mathrm{C}_{7} \mathrm{D}_{8}\right) \delta 207.3(\mathrm{t}, J=6.2 \mathrm{~Hz}, \mathrm{CO}), 74.3(\mathrm{t}, J=$ $\left.3.8 \mathrm{~Hz}, \mathrm{CH}_{2}\right), 63.9$ (t, $\left.J=7.8 \mathrm{~Hz}, \mathrm{CH}_{2}\right), 31.8$ (br s, $\mathrm{CH}_{\mathrm{iPr}}$ ), 17.1 (br s, $\left.\mathrm{CH}_{3 i \mathrm{Pr}}\right), 16.7$ (br s, $\mathrm{CH}_{3 i \mathrm{Pr}}$ ).

NMR scale synthesis of complexes $1 \boldsymbol{e}$ ' and $\mathbf{1} \boldsymbol{e}$ ". The NMR tube containing the solution of $\mathbf{1 d}$ in toluene- $d_{8}$, obtained at the previous step, was pressurized with $\mathrm{H}_{2}$ (2 bar). NMR spectra were recorded after $18 \mathrm{~h}$ of reaction at r.t. Single crystals suitable for X-Ray diffraction studies were obtained by slow evaporation in the glovebox.

Complex 1e'.

${ }^{1} \mathrm{H}$ NMR (400 MHz, toluene- $d_{8}$ ) $\delta 3.74-3.65$ (m, 2H), 3.40 - 3.30 $(\mathrm{m}, 2 \mathrm{H}), 2.38-2.29(\mathrm{~m}, 2 \mathrm{H}), 2.20-2.10(\mathrm{~m}, 4 \mathrm{H}), 1.84-1.79(\mathrm{~m} 2 \mathrm{H})$, $1.43-1.25(\mathrm{~m}, 24 \mathrm{H}),-2.45(\mathrm{t}, J=25.9 \mathrm{~Hz}, 1 \mathrm{H})$.

${ }^{31} \mathrm{P}\left\{{ }^{1} \mathrm{H}\right\}$ NMR $\left(162 \mathrm{MHz}\right.$, toluene- $\left.d_{8}\right): \delta 157.8$

${ }^{13} \mathrm{C}\left\{{ }^{1} \mathrm{H}\right\}$ NMR $(101 \mathrm{MHz}$, toluene- $d 8) \delta 67.2,56.8(\mathrm{t}, J=3 \mathrm{~Hz})$, $33.9(\mathrm{t}, J=14 \mathrm{~Hz}), 33.3(\mathrm{t}, J=16 \mathrm{~Hz}), 18.6(\mathrm{t}, J=3 \mathrm{~Hz}), 18.1(\mathrm{t}$, $J=2 \mathrm{~Hz}), 17.9,17.6$.(CO signals were not detected)

Complex 1e".

${ }^{1} \mathrm{H}$ NMR (400 MHz, toluene- $\left.d_{8}\right): \delta 3.57-3.47(\mathrm{~m}, 2 \mathrm{H}), 3.23-3.15$ (m, $2 \mathrm{H}), 2.38-2.29(\mathrm{~m}, 2 \mathrm{H}), 2.20-2.10(\mathrm{~m}, 4 \mathrm{H}), 1.84-1.79(\mathrm{~m} 2 \mathrm{H})$, $1.43-1.25(\mathrm{~m}, 24 \mathrm{H}),-2.07(\mathrm{t}, J=28.8 \mathrm{~Hz}, 1 \mathrm{H})$.

${ }^{31} \mathrm{P}\left\{{ }^{1} \mathrm{H}\right\}$ NMR $(162 \mathrm{MHz}$, toluene- $d 8): \delta 153.5$.

General procedure for hydrogenation reactions.

In an argon filled glove box, an autoclave was charged with complex $1 \mathbf{b}(6.6 \mathrm{mg}, 0.5 \mathrm{~mol} \%)$ and toluene $(2.0 \mathrm{~mL})$, followed by ketone $(2 \mathrm{mmol})$ and $t \mathrm{BuOK}(2.2 \mathrm{mg}, 1.0 \mathrm{~mol} \%)$, in this order. The autoclave was then charged with $\mathrm{H}_{2}$ (50 bar). The mixture was stirred for $20 \mathrm{~h}$ at $120{ }^{\circ} \mathrm{C}$ in an oil bath. The solution was then diluted with ethyl acetate $(2.0 \mathrm{~mL})$ and filtered through a small pad of silica $(2 \mathrm{~cm}$ in a Pasteur pipette). The silica was washed with ethyl acetate $(5 \mathrm{~mL})$. The filtrate was evaporated and the crude residue was purified by column chromatography $\left(\mathrm{SiO}_{2}\right.$, mixture of petroleum ether/ethyl acetate as eluent). For specific conditions, see in the main article. For the characterization of the product of the catalysis, see the Supporting Information.

\section{Supporting Information}

NMR spectra giving characterization of complexes and products of catalysis, X-Ray data tables. Complete details of the X-ray analyses reported herein have been deposited at the Cambridge Crystallographic Data Center (CCDC 1815476-1815481). These data can be obtained free of charge via www.ccdc.cam.ac.uk/data_request/cif, or by emailing data_request@ccdc.cam.ac.uk or by contacting the Cambridge Crystallographic Data Centre, 12 Union Road, Cambridge CD2 1EZ, UK; fax: +44 1223336033

The Supporting Information is available free of charge on the ACS Publications website.

\section{AUTHOR INFORMATION}

\section{Corresponding Author}

* Prof. Dr. Jean-Baptiste Sortais, jean-baptiste.sortais@lcctoulouse.fr.

\section{Funding Sources}

Agence National de la Recherche (ANR agency, program JCJC ANR-15-CE07-0001 "Ferracycles"), European Commission (H2020-RIA project COSMOS, grant 635405), Institut Universitaire de France, Université de Rennes 1, Centre National de la Recherche Scientifique.

Notes

The authors declare no competing financial interests.

\section{ACKNOWLEDGMENT}

We thank the Centre National de la Recherche Scientifique (CNRS), the Université de Rennes 1, Fonds Européens de Développement Economique Régional (FEDER founds), INCREASE FR-CNRS 3707, European Commission as part of H2020-RIA project COSMOS (grant 635405), l'Institut Universitaire de France (IUF) and the Agence Nationale de la Recherche (ANR agency, program JCJC ANR-15-CE07-0001 "Ferracycles").

\section{REFERENCES}

1. De Vries, J. G.; Elsevier, C. J., The Handbook of Homogeneous Hydrogenation. WILEY-VCH: Weinhem, 2007.

2. (a) Valyaev, D. A.; Lavigne, G.; Lugan, N., Manganese organometallic compounds in homogeneous catalysis: Past, present, and prospects. Coord. Chem. Rev. 2016, 308, 191-235; (b) Kuninobu, Y.; Takai, K., Organic Reactions Catalyzed by Rhenium Carbonyl Complexes. Chem. Rev. 2011, 111, 1938-1953.

3. (a) Weil, T. A.; Metlin, S.; Wender, I., The $\mathrm{Mn}_{2}(\mathrm{CO})_{10}$ catalyzed hydrogenation and hydroformylation of olefins. J. Organomet. Chem. 1973, 49, 227-232; (b) Fish, R. H.; Thormodsen, A. D.; Cremer, G. A., Homogeneous catalytic hydrogenation. 1. Regiospecific reductions of polynuclear aromatic and polynuclear heteroaromatic nitrogen compounds catalyzed by transition metal carbonyl hydrides. J. Am. Chem. Soc. 1982, 104, 5234-5237; (c) Cann, K.; Cole, T.; Slegeir, W.; Pettit, R., Catalytic reductions using carbon monoxide and water in place of hydrogen. 2. Reduction of aromatic nitro compounds to amines. J. Am. Chem. Soc. 1978, 100, 3969-3971; (d) Bogdan, P. L.; Sullivan, P. J.; Donovan, T. A.; Atwood, J. D., Photocatalysis of hydrogenation and isomerization of alkenes by cis$\mathrm{HMn}(\mathrm{CO})_{4} \mathrm{PPh}_{3}$. J. Organomet. Chem. 1984, 269, c51-c54.

4. (a) Baudry, D.; Ephritikhine, M.; Felkin, H., The activation of C$\mathrm{H}$ bonds in cyclopentane by bis(phosphine)rhenium heptahydrides. $J$. Chem. Soc., Chem. Commun. 1980, 1243-1244; (b) Baudry, D.; Ephritikhine, M.; Felkin, H.; Holmes-Smith, R., The selective catalytic conversion of cycloalkanes into cycloalkenes using a soluble 
rhenium polyhydride system. J. Chem. Soc., Chem. Commun. 1983 788-789.

5. DeWit, D. G.; Folting, K.; Streib, W. E.; Caulton, K. G., Selective hydrogenation of acenapthylene by $\mathrm{ReH}_{7}\left(\mathrm{PCy}_{3}\right)_{2}$. Organometallics 1985, 4, 1149-1153.

6. (a) Jiang, Y.; Berke, H., Dehydrocoupling of dimethylamineborane catalysed by rhenium complexes and its application in olefin transfer-hydrogenations. Chem. Commun. 2007, 3571-3573; (b) Choualeb, A.; Maccaroni, E.; Blacque, O.; Schmalle, H. W.; Berke, H., Rhenium Nitrosyl Complexes for Hydrogenations and Hydrosilylations. Organometallics 2008, 27, 3474-3481; (c) Dudle, B.; Rajesh, K.; Blacque, O.; Berke, H., Rhenium in Homogeneous Catalysis: [ReBrH(NO)(labile ligand)(large-bite-angle diphosphine)] Complexes as Highly Active Catalysts in Olefin Hydrogenations. $J$. Am. Chem. Soc. 2011, 133, 8168-8178; (d) Rajesh, K.; Dudle, B.; Blacque, O.; Berke, H., Homogeneous Hydrogenations of Nitriles Catalyzed by Rhenium Complexes. Adv. Synth. Catal. 2011, 353, 1479-1484; (e) Jiang, Y.; Huang, W.; Schmalle, H. W.; Blacque, O.; Fox, T.; Berke, H., Efficient Lewis Acid Promoted Alkene Hydrogenations Using Dinitrosyl Rhenium(-I) Hydride Catalysts. Organometallics 2013, 32, 7043-7052; (f) Jiang, Y.; Schirmer, B.; Blacque, O.; Fox, T.; Grimme, S.; Berke, H., The "Catalytic Nitrosyl Effect": NO Bending Boosting the Efficiency of Rhenium Based Alkene Hydrogenations. J. Am. Chem. Soc. 2013, 135, 4088-4102.

7. Landwehr, A.; Dudle, B.; Fox, T.; Blacque, O.; Berke, H., Bifunctional Rhenium Complexes for the Catalytic TransferHydrogenation Reactions of Ketones and Imines. Chem. Eur. J. 2012, $18,5701-5714$

8. Choualeb, A.; Lough, A. J.; Gusev, D. G., Hydridic Rhenium Nitrosyl Complexes with Pincer-Type PNP Ligands. Organometallics 2007, 26, 3509-3515.

9. (a) Radosevich, A. T.; Melnick, J. G.; Stoian, S. A.; Bacciu, D.; Chen, C.-H.; Foxman, B. M.; Ozerov, O. V.; Nocera, D. G., Ligand Reactivity in Diarylamido/Bis(Phosphine) PNP Complexes of $\mathrm{Mn}(\mathrm{CO})_{3}$ and $\operatorname{Re}(\mathrm{CO})_{3}$. Inorg. Chem. 2009, 48, 9214-9221; (b) Ozerov, O. V.; Huffman, J. C.; Watson, L. A.; Caulton, K. G., Conversion of Ethylene to Hydride and Ethylidyne by an Amido Rhenium Polyhydride. Organometallics 2003, 22, 2539-2541; (c) Ozerov, O. V.; Watson, L. A.; Pink, M.; Caulton, K. G., Transformation of Acyclic Alkenes to Hydrido Carbynes by (PNPR)Re Complexes. J. Am. Chem. Soc. 2004, 126, 6363-6378; (d) Ozerov, O. V.; Watson, L. A.; Pink, M.; Caulton, K. G., Operationally Unsaturated Pincer/Rhenium Complexes Form Metal Carbenes from Cycloalkenes and Metal Carbynes from Alkanes. J. Am. Chem. Soc. 2007, 129, 6003-6016; (e) Porchia, M.; Tisato, F.; Refosco, F.; Bolzati, C.; Cavazza-Ceccato, M.; Bandoli, G.; Dolmella, A., New Approach to the Chemistry of Technetium(V) and Rhenium(V) Phenylimido Complexes: Novel $[\mathrm{M}(\mathrm{NPh}) \mathrm{PNP}]^{3+}$ Metal Fragments $(\mathrm{M}=\mathrm{Tc}, \mathrm{Re}$; $\mathrm{PNP}=$ Aminodiphosphine) Suitable for the Synthesis of Stable Mixed-Ligand Compounds. Inorg. Chem. 2005, 44, 47664776; (f) Tisato, F.; Refosco, F.; Porchia, M.; Bolzati, C.; Bandoli, G.; Dolmella, A.; Duatti, A.; Boschi, A.; Jung, C. M.; Pietzsch, H.-J.; Kraus, W., The Crucial Role of the Diphosphine Heteroatom X in the Stereochemistry and Stabilization of the Substitution-Inert $[\mathrm{M}(\mathrm{N})(\mathrm{PXP})]^{2+}$ Metal Fragments $(\mathrm{M}=\mathrm{Tc}, \mathrm{Re} ; \mathrm{PXP}=$ Diphosphine Ligand). Inorg. Chem. 2004, 43, 8617-8625; (g) Bolzati, C.; Refosco, F.; Cagnolini, A.; Tisato, F.; Boschi, A.; Duatti, A.; Uccelli, L.; Dolmella, A.; Marotta, E.; Tubaro, M., Synthesis, Solution-State and Solid-State Structural Characterization of Monocationic Nitrido Heterocomplexes $[\mathrm{M}(\mathrm{N})(\mathrm{DTC})(\mathrm{PNP})]^{+}\left(\mathrm{M}={ }^{99} \mathrm{Tc}, \mathrm{Re} ; \mathrm{DTC}=\right.$ Dithiocarbamate; PNP $=$ Heterodiphosphane). Eur. J. Inorg. Chem. 2004, 1902-1913; (h) Kim, Y.-S.; Hea, Z.; Schibli, R.; Liu, S., Synthesis, characterization and $\mathrm{X}$-ray crystal structure of $\left[\mathrm{Re}(\mathrm{L} 4)(\mathrm{CO})_{3}\right] \mathrm{Br} \quad 2 \mathrm{CH}_{3} \mathrm{OH} \quad(\mathrm{L} 4 \quad=\quad N, N$-bis $[(2$ diphenylphosphino)ethyl]methoxyethylamine): A model compound for novel cationic ${ }^{99 \mathrm{~m}} \mathrm{Tc}(\mathrm{I})$-tricarbonyl radiotracers useful for heart imaging. Inorg. Chim. Acta 2006, 359, 2479-2488; (i) Klopsch, I.; Finger, M.; Würtele, C.; Milde, B.; Werz, D. B.; Schneider, S., Dinitrogen Splitting and Functionalization in the Coordination Sphere of Rhenium. J. Am. Chem. Soc. 2014, 136, 6881-6883; (j) Klopsch, I.; Kinauer, M.; Finger, M.; Würtele, C.; Schneider, S., Conversion of
Dinitrogen into Acetonitrile under Ambient Conditions. Angew. Chem. Int. Ed. 2016, 55, 4786-4789; (k) Vogt, M.; Nerush, A.; Diskin-Posner, Y.; Ben-David, Y.; Milstein, D., Reversible $\mathrm{CO}_{2}$ binding triggered by metal-ligand cooperation in a rhenium(i) PNP pincer-type complex and the reaction with dihydrogen. Chem. Sci. 2014, 5, 2043-2051; (1) Vogt, M.; Nerush, A.; Iron, M. A.; Leitus, G.; Diskin-Posner, Y.; Shimon, L. J. W.; Ben-David, Y.; Milstein, D., Activation of Nitriles by Metal Ligand Cooperation. Reversible Formation of Ketimido- and Enamido-Rhenium PNP Pincer Complexes and Relevance to Catalytic Design. J. Am. Chem. Soc. 2013, 135, 17004-17018.

10. (a) Wei, D.; Roisnel, T.; Darcel, C.; Clot, E.; Sortais, J.-B., Hydrogenation of Carbonyl Derivatives with a Well-Defined Rhenium Precatalyst. ChemCatChem 2017, 9, 80-83; (b) Jin, H.; Xie, J.; Pan, C.; Zhu, Z.; Cheng, Y.; Zhu, C., Rhenium-Catalyzed Acceptorless Dehydrogenative Coupling via Dual Activation of Alcohols and Carbonyl Compounds. ACS Catal. 2013, 3, 2195-2198; (c) Abdukader, A.; Jin, H.; Cheng, Y.; Zhu, C., Rhenium-catalyzed amination of alcohols by hydrogen transfer process. Tetrahedron Lett. 2014, 55, 4172-4174; (d) Schleker, P. P. M.; Honeker, R.; Klankermayer, J.; Leitner, W., Catalytic Dehydrogenative Amide and Ester Formation with Rhenium-Triphos Complexes. ChemCatChem 2013, 5, 1762-1764; (e) Piehl, P.; Pena-Lopez, M.; Frey, A.; Neumann, H.; Beller, M., Hydrogen autotransfer and related dehydrogenative coupling reactions using a rhenium(i) pincer catalyst. Chem. Commun. 2017, 53, 3265-3268.

11. Elangovan, S.; Topf, C.; Fischer, S.; Jiao, H.; Spannenberg, A.; Baumann, W.; Ludwig, R.; Junge, K.; Beller, M., Selective Catalytic Hydrogenations of Nitriles, Ketones and Aldehydes by Well-Defined Manganese Pincer Complexes. J. Am. Chem. Soc. 2016, 138, 88098814.

12. (a) Li, H.; Zheng, B.; Huang, K.-W., A new class of $\mathrm{PN}_{3}$-pincer ligands for metal-ligand cooperative catalysis. Coord. Chem. Rev. 2015, 293-294, 116-138; (b) Gunanathan, C.; Milstein, D., MetalLigand Cooperation by Aromatization-Dearomatization: A New Paradigm in Bond Activation and "Green" Catalysis. Acc. Chem. Res. 2011, 44, 588-602.

13. Kuriyama, W.; Matsumoto, T.; Ogata, O.; Ino, Y.; Aoki, K.; Tanaka, S.; Ishida, K.; Kobayashi, T.; Sayo, N.; Saito, T., Catalytic hydrogenation of esters. development of an efficient catalyst and processes for synthesising $(R)-1,2$-propanediol and 2-( $l$ menthoxy)ethanol. Org. Process Res. Dev. 2012, 16, 166-171.

14. (a) Chakraborty, S.; Dai, H.; Bhattacharya, P.; Fairweather, N. T.; Gibson, M. S.; Krause, J. A.; Guan, H., Iron-Based Catalysts for the Hydrogenation of Esters to Alcohols. J. Am. Chem. Soc. 2014, 136, 7869-7872; (b) Chakraborty, S.; Lagaditis, P. O.; Förster, M.; Bielinski, E. A.; Hazari, N.; Holthausen, M. C.; Jones, W. D.; Schneider, S., Well-Defined Iron Catalysts for the Acceptorless Reversible Dehydrogenation-Hydrogenation of Alcohols and Ketones. ACS Catal. 2014, 4, 3994-4003; (c) Chakraborty, S.; Brennessel, W. W.; Jones, W. D., A Molecular Iron Catalyst for the Acceptorless Dehydrogenation and Hydrogenation of $\mathrm{N}$-Heterocycles. J. Am. Chem. Soc. 2014, 136, 8564-8567; (d) Bornschein, C.; Werkmeister, S.; Wendt, B.; Jiao, H.; Alberico, E.; Baumann, W.; Junge, H.; Junge, K.; Beller, M., Mild and selective hydrogenation of aromatic and aliphatic (di)nitriles with a well-defined iron pincer complex. Nat. Commun. 2014, 5; (e) Werkmeister, S.; Junge, K.; Wendt, B.; Alberico, E.; Jiao, H.; Baumann, W.; Junge, H.; Gallou, F.; Beller, M., Hydrogenation of Esters to Alcohols with a WellDefined Iron Complex. Angew. Chem. Int. Ed. 2014, 53, 8722-8726.

15. (a) Zhang, G.; Scott, B. L.; Hanson, S. K., Mild and Homogeneous Cobalt-Catalyzed Hydrogenation of $\mathrm{C}=\mathrm{C}, \mathrm{C}=\mathrm{O}$, and $\mathrm{C}=\mathrm{N}$ Bonds. Angew. Chem. Int. Ed. Engl. 2012, 51, 12102-12106; (b) Zhang, G.; Hanson, S. K., Cobalt-catalyzed transfer hydrogenation of $\mathrm{C}=\mathrm{O}$ and $\mathrm{C}=\mathrm{N}$ bonds. Chem. Commun. 2013, 49, 10151-10153; (c) Zhang, G.; Vasudevan, K. V.; Scott, B. L.; Hanson, S. K., Understanding the Mechanisms of Cobalt-Catalyzed Hydrogenation and Dehydrogenation Reactions. J. Am. Chem. Soc. 2013, 135, 86688681.

16. (a) Vasudevan, K. V.; Scott, B. L.; Hanson, S. K., Alkene Hydrogenation Catalyzed by Nickel Hydride Complexes of an 
Aliphatic PNP Pincer Ligand. Eur. J. Inorg. Chem. 2012, 4898-4906; (b) Schneck, F.; Finger, M.; Tromp, M.; Schneider, S., Chemical Non-Innocence of an Aliphatic PNP Pincer Ligand. Chem. Eur. J. 2017, 23, 33-37.

17. Elangovan, S.; Neumann, J.; Sortais, J.-B.; Junge, K.; Darcel, C.; Beller, M., Efficient and selective $N$-alkylation of amines with alcohols catalysed by manganese pincer complexes. Nat. Commun. 2016, 7, 12641 .

18. (a) Danopoulos, A. A.; Edwards, P. G., Preparation and characterization of new terdentate aminodiphosphines and corresponding vanadium(III) dialkylamides. Polyhedron 1989, 8, 1339-1344; (b) Danopoulos, A. A.; Wills, A. R.; Edwards, P. G., The synthesis of tridentate dialkylamino ligands containing tertiary phosphorus or arsenic donors. Polyhedron 1990, 9, 2413-2418.

19. (a) Conley, B. L.; Pennington-Boggio, M. K.; Boz, E.; Williams, T. J., Discovery, Applications, and Catalytic Mechanisms of Shvo's Catalyst. Chem. Rev. 2010, 110, 2294-2312; (b) Doucet, H.; Ohkuma, T.; Murata, K.; Yokozawa, T.; Kozawa, M.; Katayama, E.; England, A. F.; Ikariya, T.; Noyori, R., trans-[ $\mathrm{RuCl}_{2}$ (phosphane) $)_{2}(1,2-$ diamine)] and Chiral trans-[ $\mathrm{RuCl}_{2}$ (diphosphane)(1,2-diamine)]: Shelf-Stable Precatalysts for the Rapid, Productive, and Stereoselective Hydrogenation of Ketones. Angew. Chem. Int. Ed. 1998, 37, 1703-1707; (c) Noyori, R.; Yamakawa, M.; Hashiguchi, S., Metal-Ligand Bifunctional Catalysis: A Nonclassical Mechanism for Asymmetric Hydrogen Transfer between Alcohols and Carbonyl Compounds. J. Org. Chem. 2001, 66, 7931-7944; (d) Ikariya, T.; Murata, K.; Noyori, R., Bifunctional transition metal-based molecular catalysts for asymmetric syntheses. Org. Biomol. Chem. 2006, 4, 393 406; (e) Clapham, S. E.; Hadzovic, A.; Morris, R. H., Mechanisms of the $\mathrm{H}_{2}$-hydrogenation and transfer hydrogenation of polar bonds catalyzed by ruthenium hydride complexes. Coord. Chem. Rev. 2004, 248, 2201-2237; (f) Morris, R. H., Asymmetric hydrogenation, transfer hydrogenation and hydrosilylation of ketones catalyzed by iron complexes. Chem. Soc. Rev. 2009, 38, 2282-2291; (g) Khusnutdinova, J. R.; Milstein, D., Metal-Ligand Cooperation. Angew. Chem. Int. Ed. 2015, 54, 12236-12273.

20. (a) Karunananda, M. K.; Mankad, N. P., Cooperative Strategies for Catalytic Hydrogenation of Unsaturated Hydrocarbons. ACS Catal. 2017, 7, 6110-6119; (b) Dub, P. A.; Gordon, J. C., MetalLigand Bifunctional Catalysis: The "Accepted" Mechanism, the Issue of Concertedness, and the Function of the Ligand in Catalytic Cycles Involving Hydrogen Atoms. ACS Catal. 2017, 7, 6635-6655; (c) Zhao, B.; Han, Z.; Ding, K., The N-H Functional Group in Organometallic Catalysis. Angew. Chem. Int. Ed. 2013, 52, 47444788.

21. (a) Agbossou, F.; Carpentier, J.-F.; Hatat, C.; Kokel, N.; Mortreux, A.; Betz, P.; Goddard, R.; Krueger, C., Neutral Rhodium(I) Aminophosphine-Phosphinite Complexes: Synthesis, Structure, and Use in Catalytic Asymmetric Hydrogenation of Activated Keto Compounds. Crystal Structure of [(S)-1-(Dicyclohexyl- phosphino)-2(((dicyclohexylphosphino)oxy)methyl)- pyrrolidine](2,4pentanedionato-O,O')rhodium(I). Organometallics 1995, 14, 24802489; (b) Jiang, S.; Quintero-Duque, S.; Roisnel, T.; Dorcet, V.; Grellier, M.; Sabo-Etienne, S.; Darcel, C.; Sortais, J.-B., Direct synthesis of dicarbonyl PCP-iron hydride complexes and catalytic dehydrogenative borylation of styrene. Dalton Trans. 2016, 45, 11101-11108.

22. (a) Sgro, M. J.; Stephan, D. W., Oxidative Addition Reactions of Bis-Aminophosphine and Bis-Phosphinite Nickel(0) Pincer Complexes. Organometallics 2012, 31, 1584-1587; (b) Sgro, M. J.; Stephan, D. W., Ni(ii), Pd(ii) and Pt(ii) complexes of PNP and PSP tridentate amino-phosphine ligands. Dalton Trans. 2012, 41, 67916802; (c) Sgro, M. J.; Stephan, D. W., Synthesis and reactivity of ruthenium tridentate bis-phosphinite ligand complexes. Dalton Trans. 2013, 42, 10460-10472.

23. Henrion, M.; Roisnel, T.; Couturier, J.-L.; Dubois, J.-L.; Sortais, J.-B.; Darcel, C.; Carpentier, J.-F., Ruthenium complexes bearing amino-bis(phosphinite) or amino-bis(aminophosphine) ligands: Application in catalytic ester hydrogenation. Mol. Catal. 2017, 432, 15-22.
24. (a) Bruneau-Voisine, A.; Wang, D.; Dorcet, V.; Roisnel, T.; Darcel, C.; Sortais, J.-B., Mono- $N$-methylation of anilines with methanol catalyzed by a manganese pincer-complex. J. Catal. 2017, 347, 57-62; (b) Bruneau-Voisine, A.; Wang, D.; Dorcet, V.; Roisnel, T.; Darcel, C.; Sortais, J.-B., Transfer Hydrogenation of Carbonyl Derivatives Catalyzed by an Inexpensive Phosphine-Free Manganese Precatalyst. Org. Lett. 2017, 19, 3656-3659; (c) Bruneau-Voisine, A.; Wang, D.; Roisnel, T.; Darcel, C.; Sortais, J.-B., Hydrogenation of ketones with a manganese $\mathrm{PN}^{3} \mathrm{P}$ pincer pre-catalyst. Catal. Commun. 2017, 92, 1-4; (d) Wang, D.; Bruneau-Voisine, A.; Sortais, J.-B., Practical (asymmetric) transfer hydrogenation of ketones catalyzed by manganese with (chiral) diamines ligands. Catal. Commun. 2018, 105, 31-36; (e) Wei, D.; Bruneau-Voisine, A.; Chauvin, T.; Dorcet, V.; Roisnel, T.; Valyaev, D.; Lugan, N.; Sortais, J.-B., Hydrogenation of Carbonyl Derivatives Catalysed by Manganese Complexes Bearing Bidentate Pyridinyl-Phosphine Ligands. Adv. Synth. Catal. 2018, 360, 676-681.

25. Salvarese, N.; Refosco, F.; Seraglia, R.; Roverso, M.; Dolmella, A.; Bolzati, C., Synthesis and characterization of rhenium(iii) complexes with $\left(\mathrm{Ph}_{2} \mathrm{PCH}_{2} \mathrm{CH}_{2}\right)_{2} \mathrm{NR}$ diphosphinoamine ligands. Dalton Trans. 2017, 46, 9180-9191.

26. (a) Dub, P. A.; Henson, N. J.; Martin, R. L.; Gordon, J. C., Unravelling the Mechanism of the Asymmetric Hydrogenation of Acetophenone by [RuX ${ }_{2}$ (diphosphine)(1,2-diamine)] Catalysts. J. Am. Chem. Soc. 2014, 136, 3505-3521; (b) Dub, P. A.; Scott, B. L.; Gordon, J. C., Why Does Alkylation of the N-H Functionality within M/NH Bifunctional Noyori-Type Catalysts Lead to Turnover? J. Am. Chem. Soc. 2017, 139, 1245-1260.

27. Kallmeier, F.; Kempe, R., Manganese Complexes for (De)Hydrogenation Catalysis: A Comparison to Cobalt and Iron Catalysts. Angew. Chem. Int. Ed. 2018, 57, 46-60.

28. Wang, D.; Astruc, D., The Golden Age of Transfer Hydrogenation. Chem. Rev. 2015, 115, 6621-6686.

29. (a) Tondreau, A. M.; Boncella, J. M., 1,2-Addition of Formic or Oxalic Acid to $-\mathrm{N}\left\{\mathrm{CH}_{2} \mathrm{CH}_{2}\left(\mathrm{PiPr}_{2}\right)\right\}_{2}$-Supported $\mathrm{Mn}$ (I) Dicarbonyl Complexes and the Manganese-Mediated Decomposition of Formic Acid. Organometallics 2016, 35, 2049-2052; (b) Nguyen, D. H.; Trivelli, X.; Capet, F.; Paul, J.-F.; Dumeignil, F.; Gauvin, R. M., Manganese Pincer Complexes for the Base-Free, Acceptorless Dehydrogenative Coupling of Alcohols to Esters: Development, Scope, and Understanding. ACS Catal. 2017, 7, 2022-2032; (c) Koehne, I.; Schmeier, T. J.; Bielinski, E. A.; Pan, C. J.; Lagaditis, P. O.; Bernskoetter, W. H.; Takase, M. K.; Würtele, C.; Hazari, N.; Schneider, S., Synthesis and Structure of Six-Coordinate Iron Borohydride Complexes Supported by PNP Ligands. Inorg. Chem. 2014, 53, 2133-2143.

30. Elangovan, S.; Garbe, M.; Jiao, H.; Spannenberg, A.; Junge, K.; Beller, M., Hydrogenation of Esters to Alcohols Catalyzed by Defined Manganese Pincer Complexes. Angew. Chem. Int. Ed. 2016, $55,15364-15368$.

31 . The presence of three absorption bands in IR probably results from the presence of two isomers, related to the relative syn or anti position of the bromide atom and the subtituent on the nitrogen atom. 
